\title{
Moderated trust - the impact of power distance and uncertainty avoidance on the consumer trust formation process in e-retailing
}

Citation for published version (APA):

Walczuch, R. M., \& Lundgren, H. (2003). Moderated trust - the impact of power distance and uncertainty avoidance on the consumer trust formation process in e-retailing. METEOR, Maastricht University School of Business and Economics. METEOR Research Memorandum No. 054 https://doi.org/10.26481/umamet.2003054

Document status and date:

Published: 01/01/2003

DOI:

10.26481/umamet.2003054

Document Version:

Publisher's PDF, also known as Version of record

Please check the document version of this publication:

- A submitted manuscript is the version of the article upon submission and before peer-review. There can be important differences between the submitted version and the official published version of record.

People interested in the research are advised to contact the author for the final version of the publication, or visit the DOI to the publisher's website.

- The final author version and the galley proof are versions of the publication after peer review.

- The final published version features the final layout of the paper including the volume, issue and page numbers.

Link to publication

\footnotetext{
General rights rights.

- You may freely distribute the URL identifying the publication in the public portal. please follow below link for the End User Agreement:

www.umlib.nl/taverne-license

Take down policy

If you believe that this document breaches copyright please contact us at:

repository@maastrichtuniversity.nl

providing details and we will investigate your claim.
}

Copyright and moral rights for the publications made accessible in the public portal are retained by the authors and/or other copyright owners and it is a condition of accessing publications that users recognise and abide by the legal requirements associated with these

- Users may download and print one copy of any publication from the public portal for the purpose of private study or research.

- You may not further distribute the material or use it for any profit-making activity or commercial gain

If the publication is distributed under the terms of Article 25fa of the Dutch Copyright Act, indicated by the "Taverne" license above, 


\title{
Moderated Trust - The Impact of Power Distance and Uncertainty Avoidance on the Consumer Trust Formation Process in E-Retailing
}

\author{
Henriette Lundgren \\ Rita Walczuch \\ Department of Accounting and Information Management, University of Maastricht, Postbus 616, \\ 6200MD Maastricht, The Netherlands \\ h.lundgren@aim.unimaas.nl; r.walczuch@aim.unimaas.nl
}

\begin{abstract}
Despite a strong interest in online trust issues, very little has been said so far about the process of trust formation in e-retailing from the perspective of national culture. The purpose of this study is to operationalize a model of trust-building processes with a set of cognitive trust antecedents. The model is then tested by comparing two samples from different power distance and uncertainty avoidance cultures. The results of this study suggest that buyers from low power distance and low uncertainty avoidance cultures tend to form trust more through a transference process, in contrast to their counterparts in high power distance and high uncertainty societies who make more use of a calculative trust formation process. The recognition of these cultural priorities is crucial to a successful e-retailing strategy.

(E-Retailing, Consumer Trust, Cognitive Antecedents, Trust Formation Process, Culture, Power Distance, Uncertainty Avoidance)
\end{abstract}




\section{Introduction}

Stimulated by the reported lack of trust in e-retailing, several authors have drawn up theoretical models and found empirical evidence for the relationship between certain psychological determinants and consumer trust on the one hand and the associated effects on consumers' purchase behavior on the other hand (Friedman et al. 2000, Gefen 2000, Heijden et al. 2000, Jarvenpaa et al. 2000, McKnight et al. 1998, Noeteberg et al. 1999, Walczuch et al. 2001). These studies result in the insight that online consumers make predominant use of cognitive factors, e.g. reputation, firm size and familiarity with the e-retailer, when evaluating the degree of trustworthiness in the online seller-buyer relationship. However, consumer trust is no longer the only barrier to a successful e-retailing strategy. Globalization and its related cross-cultural obstacles have been brought into the limelight. As a consequence, several authors call for drawing closer attention to the impact that culture has on online consumer behavior (Jarvenpaa and Tractinsky 1999, Kim et al. 2001, Lynch et al. 2001).

Since the introduction of the World Wide Web as a new tool for commercial transactions, the tendency of large e-retailers - most of them originating in North America - to adopt a global Internet strategy can be noted (Lynch et al. 2001). At the end of 2002, 600 million people worldwide were forecasted to be online, making purchases over the Internet amounting to US\$ 1 trillion (Grant 2002). The larger part of these revenues come from North American users. Nevertheless, European Internet purchasers are catching up. As a recent research report summarizes, half of all online revenue will come from outside the United States by 2004 (Raven and Fleenor 2002). In addition, a study on consumer behavior divergence has shown that international market participants do react differently across cultures to marketing campaigns and that therefore consumer behavior is not converging (de Mooij 2001).

Having realized the need for diverging and thus nationally-localized e-retailing strategies, several scholars have conducted research studies on the effect of culture on the perception of storefront websites (French et al. 2002, Kang and Corbitt 2001, Karvonen et al. 2000, Kersten et al. 2000, Smith et al. 2002). These studies focused on the impact of website design features - graphical cues, trust seals and brand names - and their effect on consumer trust in different countries, and related the trust outcomes to the underlying cultural norms and beliefs. 
Despite this interest in website trust issues, very little has been said so far about the process of trust formation in e-retailing from the perspective of national culture. In this context, studies suggest that cognitive, rather than affective, components are most influential in the online environment (Sambamurthy and Jarvenpaa 2002). One step towards a thorough understanding of this topic is the integrated model of trust that describes in a theoretical setting the effect of national culture on five cognitive trust-building processes (Doney et al. 1998). However, no empirical evidence bringing to light differences in online consumer trust between various countries has been published for this framework so far.

Within the industrialized world, a strong chasm in Internet adoption exists between Northern Europe and Northern America on the one hand and Latin European countries on the other hand, with France, Spain, Portugal and Italy considerably lagging behind (Singh et al. 2001). Since all these countries have sufficiently high economic resources, one potential reason for the difference could be culture. Coincidently, trust levels are in general lower in these Latin European countries (Fukuyama 1995, Hofstede 1997). Therefore, this paper attempts to shed some light on the following questions: What is the actual effect of culture on the antecedents of consumer trust in eretailing? Can it be demonstrated that certain cultures tend to be more trusting than others? And if so, how does culture influence the trust formation process?

The purpose of this paper is to identify the influence that national culture has on the different trust-building processes. This study is thus an attempt to operationalize an integrated model of trust by testing the impact of national culture on the effect of established cognitive trust antecedents on institution-based consumer trust in e-retailing.

The paper will continue as follows: An integrated model of the effect of national culture on the cognitive trust formation processes is first described and then operationalized with validated consumer trust antecedents. From this trust formation model, research hypotheses are developed. Thirdly, the research methodology is explained. Next, the results of the cross-cultural validation are depicted and finally the findings are discussed.

\section{The Impact of Power Distance and Uncertainty Avoidance on the Consumer Trust Formation Process}

When looking at the cultural differences between the U.S.A. and Latin Europe, different positions on Hofstede's (1997) cultural dimensions can be identified. Whereas the U.S.A. score low on 
both power distance and uncertainty avoidance, all Latin European countries can be characterized as relatively high power distance and high uncertainty avoidance cultures (Hofstede 1983). In the remaining dimensions - individualism and masculinity - no major differences between the countries can be detected (Hofstede 1983). Thus, when comparing Latin Europe to the U.S.A., power distance and uncertainty avoidance are the dimensions that distinguish these two culture groups. Therefore, this research focuses on these two dimensions.

According to a comparative research study on Internet adoption barriers, the lower adoption rate of the Internet in Europe in general can be explained by the higher degree of uncertainty avoidance in Latin European countries, i.e. France, Spain, Portugal and Italy, as compared to the United States (Singh et al. 2001). The uncertainty avoidance dimension depicts the degree of uncertainty or ambiguity that a particular community finds tolerable (Hofstede 1997). Countries that strongly avoid uncertainty tend to maintain rigid beliefs and behavior. These cultures are intolerant to people and ideas that diverge from the norm and have a strong need to safeguard themselves against hazardous behavior. High uncertainty avoidance cultures are resistant to change, believe in strong relationships, and rely on expertise. In cultures with less anxiety towards the future, on the other hand, practice counts more than principles and conflicts are more easily accepted.

Moreover, Fukuyama found the U.S.A. to be a high trust society whereas Italy, as a representative of Latin Europe, can be categorized as a low trust society (Fukuyama 1995). These findings can be explained by the fact that the U.S. score relatively lower on power distance as compared to the Latin European countries (Hofstede 1997). Power distance is understood as the dimension that indicates the extent to which members of a society can and do accept that power in institutions and organizations is distributed unequally (Hofstede 1997). Citizens of high power distance countries will typically accept a hierarchical order and engage in opportunistic behavior. In addition, social relationships are based on rivalry and distrust rather than on mutual dependence. In countries with a smaller power distance, where dependency and conformity are low and egalitarianism exists, the population may demand justification for inequalities in power. Combined with the findings of relative trust levels, one might suggest that the degree to which members of a society accept an unequal distribution of power negatively effects the absolute level of trust in a society. 
According to a recent comprehensive review of trust definitions by Gefen et al. (2003) trust is typically defined as "(1) a set of specific beliefs dealing primarily with the integrity, benevolence, and ability of another party [...], (2) a general belief that another party can be trusted [...], (3) affect reflected in feelings of confidence and security in the caring response of the other party (Rempel et al. 1985, p.96), or (4) a combination of these elements" (Gefen et al. 2003 p. 55).

In this trust study, the focus is on 'institution-based consumer trust' since the intention is to measure consumer trust in general and not, like many other studies, specific consumer trust in an existing e-retailer. Following this focus, the second definition of trust as a "general belief that another party can be trusted" (Gefen et al. 2003) is adopted in this paper. Other authors have named this type of trust "trusting intentions" (McKnight et al. 1998) or "the willingness of a party to be vulnerable to the actions of another" (Mayer and Davis 1995, p. 712). For reasons of simplification, whenever the term (consumer) trust is used in this paper, institution-based consumer trust is meant.

Consumers form expectations and thus trust by using different methods and different sources of information. The trustor (buyer) engages in one or more cognitive processes in order to find out whether the target (seller) is trustworthy. In the cognitive trust formation model (Doney et al. 1998), five different trust formation processes are depicted, namely:

1. Calculative process;

2. Prediction process;

3. Capability process;

4. Intentionality process; and

5. Transference process

In the following sections, these five trust formation processes are described and form, together with the associated cognitive antecedents of consumer trust, the basis of the hypotheses formulation. Figure 1 depicts the hypothesized impact of the dimensions power distance and uncertainty avoidance on the trust building processes. 


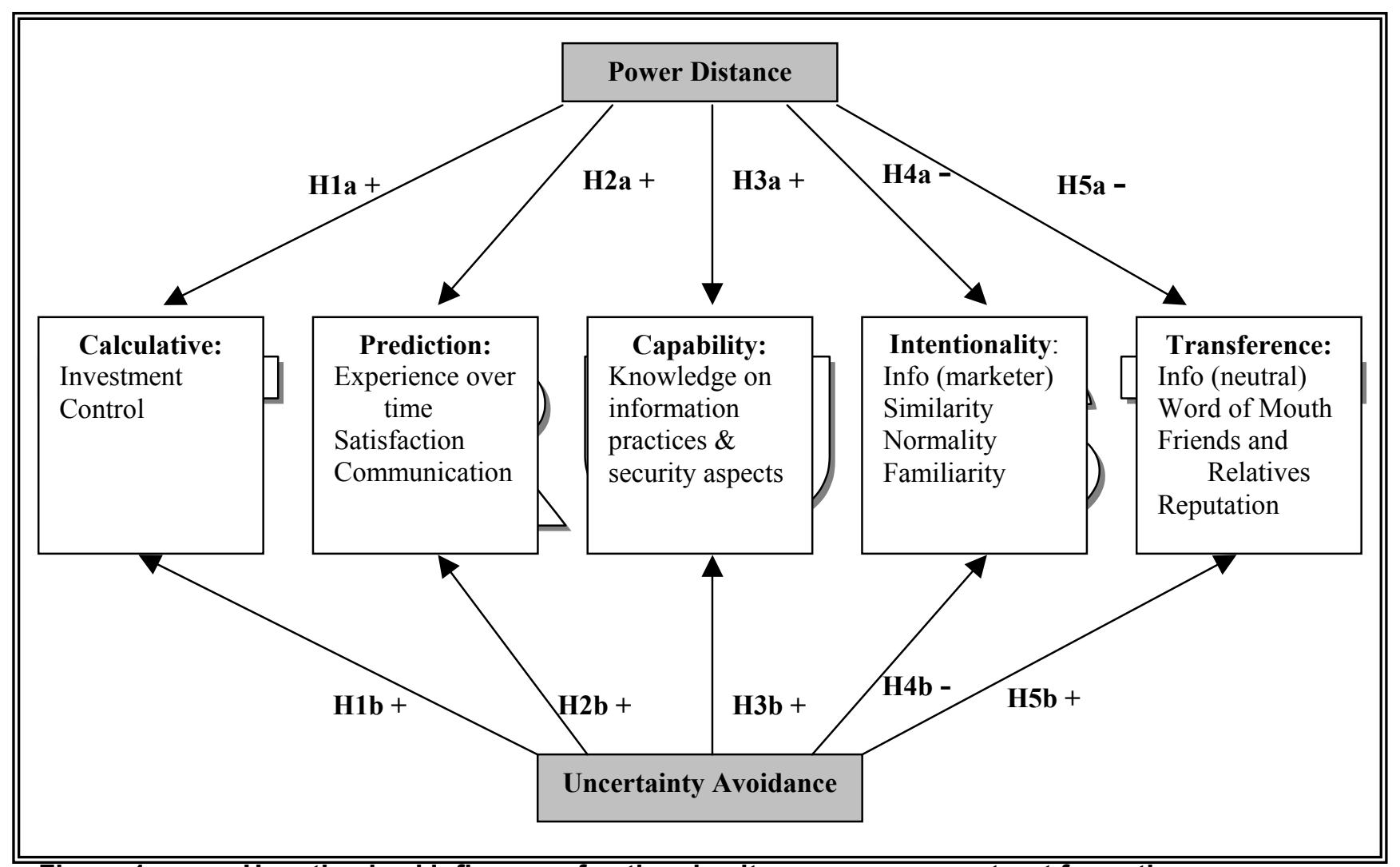

Figure 1 Hypothesized influence of national culture on consumer trust formation processes

\subsection{Calculative Process}

In order to create trust via a calculative trust formation process, the trustor must determine whether the targets' costs for opportunistic behavior exceed the benefits (Doney et al. 1998). Stated differently, the consumer performs a sort of net present value calculation to determine the degree of trustworthiness of the e-retailer.

Several authors support the statement that a large organization size implies that an e-retailer has invested significant resources and has much to lose when behaving untrustfully (Ganesan 1994, Heijden et al. 2000, Jarvenpaa and Tractinsky 1999). Thus, the higher the losses that sellers will incur if they violate consumer trust, the less likely they are to actually show untrustful behavior. In addition, opportunistic behavior of an e-retailer can be minimized by installing control mechanisms. Control in this context can be seen as the consumer's perceived power to influence the other person's outcome and thereby to reduce the incentive for the target to engage in untrustworthy behavior (Deutsch 1958). Furthermore, trust requires a surrender of a certain amount of control to the trustor (Nooteboom 2002). Thus, depending on the perceived degree of control in the buyer-seller relationship, buyers trust more.

The question arises to what extent the trustor's cultural background plays a role in forming trust through this calculative process. Doney et al (1998) state that the power distance dimension 
positively influences the likelihood that targets will show opportunistic behavior. The rewards and losses are being calculated in order to evaluate whether trust in a particular situation or relationship is beneficial to the trustor. Whereas opportunism might be less likely in low power distance cultures, high power distance countries might act opportunistically. In the context of consumer trust in e-retailing, this statement indicates that consumers from relatively high power distance cultures will make more use of a calculative process in determining the trustworthiness of an e-retailer compared to consumers from low power distance cultures. Therefore, the first hypothesis can be stated as follows:

$H_{1 a}:$ Relative to counterparts in low power distance cultures, consumers in high power distance cultures are more likely to form consumer trust in e-retailing via a calculative process.

When talking about the culture dimension of uncertainty avoidance, the degree to which a society tolerates uncertainty plays a role in the buyer-seller relationship. The original cognitive trust formation model (Doney et al. 1998) proposes that low uncertainty avoidance is related to a the calculative trust formation process, because opportunistic behavior is more likely in these cultures and thus calculative processes are more important. Opposed to this, we argue here that high uncertainty avoidance cultures feel a strong need to safeguard themselves against possibly hazardous behavior in their trust relationship (Nooteboom 2002). Therefore, precise facts and figures are very important to judge the target's trustworthiness. This leads to the hypothesis that consumers from high uncertainty avoidance cultures tend to form trust more strongly by taking into account control and perceived investment issues, thus, using a calculative trust formation process compared to consumers from low uncertainty avoidance cultures:

$H_{1 b}:$ Relative to counterparts in low uncertainty avoidance cultures, consumers in high uncertainty avoidance cultures are more likely to form consumer trust in e-retailing via a calculative process.

\subsection{Prediction Process}

Trust is built via a prediction process if a trustor determines that a target's past actions provide a stable basis upon which future behavior can be predicted (Doney et al. 1998). Assumingly, predictability of the target will lead to trust (Triandis 1994). Hence, prior experience is used to engage in a prediction process to determine the trustworthiness of e-retailers. This experience does not necessarily have to be in e-retailing itself. General web experience will be positively related to institution-based trust because experience provides the consumer with a feeling of 
security and normality (McKnight et al. 2002). Thus, the antecedent 'experience over time' falls under the category of prediction.

Furthermore, suggests that consumers' satisfaction with past outcomes indicates equity in the buyer-seller relationship (Ganesan 1994). This satisfaction provides the consumer with confidence in future relationships. From prior experience, future action will be predicted.

A similar process is initiated when consumers evaluate past communication patterns between themselves and the e-retailers. The degree to which relevant, reliable and timely information is shared furthermore impacts the trust relationship (Deutsch 1958). The more an e-retailer shares information with a customer, the higher the trust in this buyer-seller relationship will be.

The culture dimension of power distance addresses the predominance of norms and conformity versus independence. In low power distance cultures, people are less likely to behave in a conforming way. In contrast, they tend to do whatever they want to do (Hofstede 1997). Conversely, in high power distance cultures, conformity prevails and norms for conformity provide the citizens of these cultures with evidence that the target's behavior is predictable. Prior communication and experience is consulted in order to evaluate the counterpart's trustworthiness. In the setting of e-retailing, consumers from cultures of high power distance tend to use their exposures to and their experience with e-retailing to predict their trust relationship significantly more compared to consumers from low power distance cultures. In order to form hypothesis $2 \mathrm{a}$, this statement can be reformulated as:

$H_{2 a}$ : Relative to counterparts in low power distance cultures, consumers in high power distance cultures are more likely to form consumer trust in e-retailing via a prediction process.

Citizens in low uncertainty avoidance cultures tolerate a wide range of behaviors and opinions. Therefore, prediction of the target's trustworthiness is not possible if the target's behavior and beliefs are not predictable. Contrastingly, the dominant trait in high uncertainty avoidance cultures is the predictability of behavior (Kale and McIntyre 1991). People in high uncertainty avoidance cultures strive for establishing clear rules as a code of conduct. Translated into a buyer-seller relationship, this signifies that consumers from a high uncertainty avoidance culture consider past shopping experience and exposure to an online storefront as reliable evidence upon which trust can be built. From this argumentation, hypothesis $2 \mathrm{~b}$ can be derived:

$H_{2 b}$ : Relative to counterparts in low uncertainty avoidance cultures, consumers in high uncertainty avoidance cultures are more likely to form consumer trust in e-retailing via a prediction process. 


\subsection{Capability Process}

To evaluate a trust relationship by means of a capability process, an assessment of the target's ability to fulfill the trustor's expectations is being conducted (Doney et al. 1998). In the field of ecommerce, this ability relates predominantly to the technical competences of the online vendors. Buyers have to evaluate whether online sellers are capable of fulfilling their obligations and thus meet the buyers' expectations. In order to be able to evaluate someone's technical competence, technical knowledge has to be possessed.

Two forms of technical knowledge that are suggested to increase institution-based consumer trust in e-retailing are 'knowledge on information practices' and 'knowledge on security aspects' (Walczuch et al. 2001). The latter one can be used to evaluate whether e-retailers are capable of technically guaranteeing the promised security features. Knowledge on information practices, on the other hand, gives the buyers insight about the seller's possibility to retrieve certain information, e.g. private data. Thus, more knowledge about a seller's capabilities increases consumer trust.

Hofstede's power distance dimension depicts the degree to which capabilities in a society are equally distributed; people in lower power distance societies demonstrate an egalitarian view towards others. Contrastingly, high power distance societies accept inequalities (Hofstede 1997). From the cognitive trust formation model it can be concluded that evidence of a target's individual capability may be discounted in low power distance countries (Doney et al. 1998). The reverse is hypothesized for high power distance societies. In these societies, a wide gap exists between experts and non-experts. Here, people expect inequalities in traits and intellectual abilities of the target. For trust in e-retailing this notion comes down to the point that buyers from high power distance societies who expect differences in e-retailers' capabilities and who can assess these capabilities with their own technical knowledge will more likely form trust through a capability process compared to buyers from low power distance societies. This leads to the fifth hypothesis:

H3a: Relative to counterparts in low power distance cultures, consumers in high power distance cultures are more likely to form consumer trust in e-retailing via a capability process.

The dimension of uncertainty avoidance determines the value placed on a target's capability. Doney et al (1998) state that in a culture with low uncertainty avoidance, people deal with risk easily, and common sense and a strong belief in generalists prevail. An examination of a target's 
technical competences is therefore unlikely for a trustor from a low uncertainty avoidance culture in order to determine the trustworthiness of the target.

However, in cultures with high risk aversion, evidence of a target's competence, ability or expertise does play a role in the formation of trust. Hofstede states that in high uncertainty avoidance cultures a strong emphasis is set on expertise (Hofstede 1997). For the online buyerseller relationship, it can be expected that consumers from high uncertainty avoidance societies make more use of a capability trust formation process compared to buyers from a low uncertainty avoidance culture. This priority is hypothesized in the following statement:

H3b: Relative to counterparts in low uncertainty avoidance cultures, consumers in high uncertainty avoidance cultures are more likely to form consumer trust in e-retailing via a capability process.

\subsection{Intentionality Process}

By making use of the intentionality process, a trustor examines a target's words and behavior in order to decide whether or not a target will behave in a trustful way. Thus, trust formation is influenced by one party's perception of the intentions of the other party (Doney et al. 1998, Kramer 1999).

Information from marketers can be a source for interpretation of intentions. A mission statement or some service delivery information produced by the e-retailers themselves can serve someone who wants to evaluate a seller's trustworthiness based upon intentions.

Secondly, if trustors perceive their targets to be similar to themselves, the level of comfort in the trust relationship is increased and higher levels of trust are likely to be reached (McKnight et al. 1998, Parkhe 1998).

Perceiving the e-retailing environment as normal can also have an effect on the interpretation of the intentions of the e-retailer. Just as perceived similarity, perceived normality, i.e. seeing conditions as normal or 'common', breeds trust. Thus, high situational normality implies for the consumer that the Internet environment is appropriate, well-ordered and favorable for doing personal business (McKnight et al. 2002).

Finally, it was found that the mere exposure of people to a certain stimulus will positively influence their evaluation of it (Brehm et al. 1998). Perceived familiarity is the exposure of a consumer to a online storefront without buying a product or service (Walczuch et al. 2001). The 
more familiar consumers are with e-retailing, the better they will be able to predict an e-retailer's intentions, and the more they will trust in e-retailing.

Relating these intention issues to the cultural dimension of power distance, standards for interpersonal interaction can either promote or inhibit the perceived trustworthiness of a target (Doney et al. 1998). In societies with high power distance, the gap between people at the top taking the decisions and those people at lower levels carrying out the orders is quite large. Under such conditions it is improbable that consumers believe in the benevolence of the e-retailer. In contrast, low power distance societies value relationships based on mutual dependence. Such norms provided in low power distance societies support buyers to form trust more through an intentionality process in contrast to buyers in high power distance cultures. From this statement, hypothesis 4a evolves:

$H_{4 a}$ : Relative to counterparts in high power distance cultures, consumers in low power distance cultures are more likely to form consumer trust in e-retailing via an intentionality process.

The uncertainty avoidance dimension determines the value citizens of a culture place on continuing already established relationships (Hofstede 1997). In low uncertainty avoidance cultures, conflict is acceptable, and people are willing to risk existing relationships. Thus, in an online store, there are several factors that can be interpreted in a trust-building process. Features, like similarity, normality and familiarity leave the buyer with the feeling that the e-retailer is trustworthy. However, these features are neither tangible nor reliable and therefore out of the comfortable range for high uncertainty avoidance cultures. People here prefer to ground their trust on sound and defendable information, like in the calculative trust formation process. Therefore, in contrast to the original integrated model of trust, which hypothesized a positive relationship between uncertainty avoidance and trust, we believe that low uncertainty avoidance culture are more likely to form consumer trust in e-retailing based on intentionality compared to buyers in a high uncertainty avoiding culture. This statement is depicted in the next hypothesis:

$H_{4 b}$ : Relative to counterparts in high uncertainty avoidance cultures, consumers in low uncertainty avoidance cultures are more likely to form consumer trust in e-retailing via an intentionality process.

\subsection{Transference Process}

Trust in the transference process can be formed if trustors transfer trust from a known entity to an unknown one. This known entity can be a trusted person or a trusted institution, through which information about the target is passed on. This kind of trust is also called 'transference-based 
trust' and this concept refers to a buyer who determines a seller's trustworthiness based on second hand information from a trusted party ( $\mathrm{Ba} 2001)$.

In order to establish trust via a transference process, buyers must be able to identify proof sources. Such proof sources can be word-of-mouth information, information from friends and relatives or information from neutral sources (Jarvenpaa and Tractinsky 1999, Kramer 1999, Walczuch et al. 2001).

A retailer's reputation has been identified as an antecedent to trust in e-retailing (McKnight et al. 2002). There has been some discussion about whether this antecedent belongs to the calculative or the transference trust formation process. Reputation is a valued asset that requires a long-term investment of resources and that its evaluation is used in opportunistic behavior (Jarvenpaa and Tractinsky 1999). In contrast to this 'sanctioning role of reputation', i.e. reputation as an assurance mechanism that reduces the incentive of the e-retailer to act dishonestly, reputation can also be looked at from an informational aspect (Yamagishi and Yamagishi 1994). Here, second hand information about a potential seller's traits is evaluated and taken as a basis for consumer trust. In this research, the latter perspective will be included in the model where reputation is seen as the passing on of second hand information.

The cognitive trust formation model states that the power distance dimension is closely associated with the willingness to place faith in others: if faith in people and institutions is high, a transference process for trust formation is triggered (Doney et al. 1998). People from high power distance societies, however, view other people as a threat and trust less. The fact that faith in people and institutions is low hinders a smooth passing on of trust from one entity to another. Conversely, people in low power distance cultures feel to be less threatened by others and tend to engage more in open relationships with others. In e-retailing, this statement would suggest that buyers from low power distance cultures engage more in a transference based trust process compared to their counterparts in high power distance societies. Thus, the following hypothesis can be formulated:

$H_{5 a}:$ Relative to counterparts in high power distance cultures, consumers in low power distance cultures are more likely to form consumer trust in e-retailing via a transference process.

The uncertainty avoidance dimension closely mirrors the "tightness" and "looseness" concepts articulated by several authors in anthropology (Hofstede 1997, Triandis and Suh 2002). Low uncertainty avoidance cultures can also be described as "loose" and are associated with little 
concern for stability and permanence in relationships. Instead, citizens of these cultures take more risks and trust other people or institutions less. The opposite is true for high uncertainty avoidance ("tight") cultures. As stated before, people are motivated to maintain existing relationships since they value stability. Buyers from a high uncertainty avoidance culture thus believe that sellers will act in the buyers' best interest to avoid conflicts and maintain existing relationships. From this assumption, the last hypothesis stating that buyers in high uncertainty avoidance cultures tend to make more use of a transference process when trusting online compared to citizens of a low uncertainty avoidance culture, can be formulated.

$H_{5 b}:$ Relative to counterparts in low uncertainty avoidance cultures, consumers in high uncertainty avoidance cultures are more likely to form consumer trust in e-retailing via a transference process.

\section{Research Methodology}

\subsection{Sample}

In order to test the hypothesized moderating effect of power distance and uncertainty avoidance, two countries, namely Italy (as a representative of Latin Europe) and the U.S., were selected. Italy holds an online population of $33.3 \%$ whereas in the U.S. $59.1 \%$ of the citizens are online (NUA 2002). Another study reports the U.S. to be on rank 1 (score 8.41) concerning e-readiness, while Italy lags behind with a score of 7.32 on rank 19 (Economist Intelligence Unit, 2002). Thus, the two countries show two distant positions concerning their level of Internet adoption. Concerning the cultural differences between these societies, Italy scores relatively high on Hofstede's Uncertainty Avoidance dimension (score 75, rank 23) as compared to the U.S.A.(score 46, rank 43) (Hofstede 1997). Furthermore, the U.S. score relatively lower on power distance (power distance index score of 40, rank 38) as compared to Italy (power distance index score equals 50, rank 34). These scores represent relative instead of absolute positions of countries and therefore only measure the difference between Italy and the U.S. being 10 points of the power distance index score (Hofstede 1997). Thus, these two countries show two distinct positions with respect to their uncertainty avoidance as well as their power distance level.

Data was collected among university students in the U.S. during 2001 (148 samples) and in Italy in fall 2001 and spring 2002 (200 samples). The same questionnaire used for the American students was translated into Italian and it was likewise administered to groups of students in a classroom setting. A normal distribution of male (45.8\%) and female (54.2\%) was collected with 
$32.2 \%$ of students who can be classified as non-buyers opposed to $67.8 \%$ of participants who have either bought or intended to buy something over the Internet. Remarkably, only $52 \%$ of the Italian students had experience with online shopping in contrast to $87 \%$ of the U.S. students who had either bought or intended to buy a product or service online.

\subsection{Survey instrument}

A 75-item paper questionnaire (the majority of the questions administered on a 5-point-Likert scale) was used for this cross-cultural validation of the trust formation model. Only a few items were answered by making use of an ordinal or nominal format. For a complete overview of all items used in this study, please consult Appendix 1.

All questions were directly translated into Italian by a bilingual person and then carefully corrected by two independent Italian reviewers. Whenever no direct translation was feasible, appropriate Italian terms were used.

In order to test the various constructs for their reliability, the Cronbach alpha calculation was used. As stated by Nunally (Nunally 1978), a Cronbach alpha of 0.50 or higher depicts a sufficient level of internal reliability. Appendix 1 summarizes the Cronbach alpha values for the tested constructs. The indicated alphas show an overall sufficient level of internal reliability. However, when examining the reliability levels for both country samples separately, significantly higher Cronbach alpha levels could be observed in the U.S. sample as compared to the Italian sample. This finding of decreasing internal reliability is an observable phenomenon in crosscultural samples and recognized in culture and social behavior studies (Triandis 1994).

For some of the constructs, however, the measurement of Cronbach alpha was not applicable. Questions about information from consumer dominated sources, from neutral sources and from marketer dominated sources as well as the items about knowledge on information practices and on security technology, experience over time, and familiarity are not making use of a construct as such but are in fact an examination of the participants' direct knowledge on or experience with these issues (Walczuch et al. 2001). The calculation of a value such as Cronbach alpha, which tests the reliability of attitudinal answers to one construct, is therefore not applicable. 


\section{Results}

Since the U.S.A. score high and Italy scores low on both researched culture dimensions, the trust formation model suggests that hypotheses 1 through 4 are tested pairwise, e.g. H1a and H1b are discussed together. Only hypotheses $5 \mathrm{a}$ and $5 \mathrm{~b}$ point in different directions and should therefore be discussed separately. But before testing the hypothesized model of the moderated trust formation processes, a simple independent sample t-test was conducted to compare the absolute levels of trust in each nation. The U.S. sample shows a trust mean of 3.05 whereas a mean of 2.54 is observed among Italian students. These two values are significantly different at a $p<0.05$ level $(\mathrm{F}=6.266)$. This indicates that, indeed, culture has an effect on trust.

The level of trust differs significantly $(F=13.35$; $<<0.00)$ between those participants who have already made purchases or intended to do so (trust mean=2.92) and those who have not made any purchases online (trust mean=2.45). Therefore, two regression models were used to test the hypothesized relationships. Model 1 includes all variables and therefore represents only the answers of buyers. Model 2, in contrast, includes those items that could be answered by buyers as well as non-buyers. This means that the variable satisfaction and all communication constructs ( independent of buying process; of expectations; of intentions; of retaliation; of absolution) are excluded from model 2.

In order to test the effect of power distance and uncertainty avoidance, however, additional interaction effects were integrated in these models. First, the variable "country" (U.S. $=0$; Italy=1) was added and tested. The results in both models show that country as an independent variable is not statistically significant and therefore does not have any direct effect on trust (C.f. Table 2). Then, interaction variables were defined as country* antecedent\} and added to the original regression models.

To determine whether the moderator "country" makes a significant contribution to the model, the estimates of the unmoderated regressions were compared to those of the moderated regression models. Table 1 shows a comparison of the R square values: 


\begin{tabular}{||l|r|r||}
\hline & Model 1 & Model 2 \\
\hline R square (unmoderated model) & 0.705 & 0.635 \\
\hline R square (moderated model) & 0.768 & 0.67 \\
\hline $\begin{array}{l}\text { Number of variables (moderated } \\
\text { model) }\end{array}$ & 40 & 28 \\
\hline Degrees of freedom 1 & 1 & 1 \\
\hline Degrees of freedom 2 & 131 & 299 \\
\hline N & 171 & 327 \\
\hline F-value & 35.573 & 31.712 \\
\hline Critical value $(\mathrm{p}<0.01)$ & 11.38 & 11.10 \\
\hline
\end{tabular}

Table 1 R square adjusted in unmoderated and moderated regressions

The figures above show that the R squares in the moderated models 1 and 2 have increased, and the F-values indicate that the change in $\mathrm{R}^{2}$ is statistically significant $(\mathrm{p}<0.01)$. The results of this test indicate that a significant moderator effect of the variable country is present in both models. We can therefore conclude that the trust formation process is indeed moderated by nationality and thus culture.

\subsection{Results of regression analyses (U.S. and ITA sample)}

The table below shows the coefficients of three regressions: two separate unmoderated country models (USA and ITA) and the interaction coefficients of the moderated model.

For the U.S. sample, six statistically significant variables with a direct effect on trust can be observed in model 1 , five of which at an alpha level of 0.01 and one at $\alpha=0.05$. For the U.S. model 2 , ten direct effects with a statistical significance of six times 0.01 and four times 0.05 were found. The adjusted $\mathrm{R}^{2}$ for U.S. models 1 and 2 equals 0.697 and 0.705 respectively. The Italian sample in model 1 yields only three statistically significant variables (one at $\alpha=0.01$, 0.05 and 0.1 each). In model 2, however, the number of significant variables increases to eight, where three direct effects in the Italian sample are significant at an alpha level of 0.01 , four at $\alpha=0.05$ and two at $\alpha=0.1$. The $\mathrm{R}$ square adjusted figures of the Italian models are relatively lower (model $1=0.471$ and model $2=0.446$ ) as compared to the coefficients of determination of the U.S. models. Table 2 presents the results all regression analyses. 


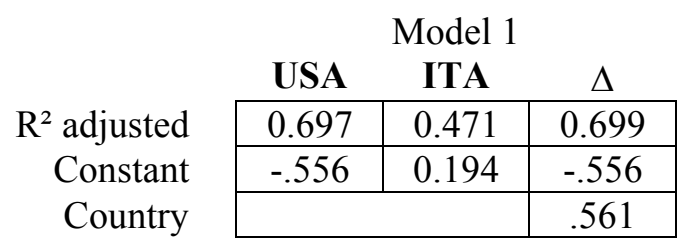

\begin{tabular}{|c|c|c|}
\hline \multicolumn{3}{|c|}{ Model 2} \\
\hline USA & ITA & $\Delta$ \\
\hline 0.705 & 0.446 & 0.641 \\
\hline$-.893 * *$ & -0.0305 & $-.893 * *$ \\
\hline & & .663 \\
\hline
\end{tabular}

\section{Calculative Process}

Perceived Investment

Perceived Control

\begin{tabular}{|c|c|c|}
\hline$-.160 * * *$ & $.233 * *$ & $.614 * * *$ \\
\hline $.301 * * *$ & $.389 * * *$ & .305 \\
\hline
\end{tabular}

\begin{tabular}{|c|c|c|}
\hline$-.137 * * *$ & $.160 * * *$ & $.466 * * *$ \\
\hline $.265 * * *$ & $.272 * * *$ & .053 \\
\hline
\end{tabular}

\section{Prediction Process}

Experience over time

Satisfaction

Comm. independent of buying process

Communication of expectations

Communication of intentions

Communication of retaliation

Communication of absolution

\begin{tabular}{|c|c|c|}
\hline .022 & .196 & .278 \\
\hline .045 & .014 & -.051 \\
\hline-.009 & -.081 & -.122 \\
\hline .096 & -.073 & -.318 \\
\hline .004 & .215 & .359 \\
\hline-.128 & .033 & .254 \\
\hline .035 & -.061 & -.103 \\
\hline
\end{tabular}

\begin{tabular}{|l|l|l|}
\hline $.148^{* * *}$ & $.169 * *$ & .017 \\
\hline
\end{tabular}

Capability Process

Knowledge on information practices

Knowledge on security issues

\begin{tabular}{|c|c|c|}
\hline .082 & .071 & -.124 \\
\hline-.053 & -.162 & -.250 \\
\hline
\end{tabular}

\begin{tabular}{|c|c|c|}
\hline $.114 * *$ & $.127 * *$ & -.103 \\
\hline-.029 & $-.107 *$ & -.165 \\
\hline
\end{tabular}

\section{Intentionality Process}

Informat. marketer dominated sources

Perceived Similarity

Perceived Normality

Perceived Familiarity

\begin{tabular}{|c|c|c|}
\hline-.030 & -.055 & -.060 \\
\hline $.152^{* *}$ & $.225^{*}$ & .072 \\
\hline .088 & .084 & -.013 \\
\hline .061 & -.123 & -.656 \\
\hline
\end{tabular}

\begin{tabular}{|c|c|c|}
\hline-.015 & -.085 & -.162 \\
\hline $.146 * * *$ & $.183 * * *$ & -.003 \\
\hline .050 & -.066 & -.196 \\
\hline $.106 * *$ & .019 & -.313 \\
\hline
\end{tabular}

Transference Process

\section{Reputation \\ Word of mouth}

Information from friends and relatives

Information from neutral sources

\begin{tabular}{|c|c|c|}
\hline $.346^{* * *}$ & .169 & -.351 \\
\hline $.154 * * *$ & -.057 & $-.250 *$ \\
\hline $.213 * * *$ & .085 & -.166 \\
\hline .032 & -.004 & -.065 \\
\hline
\end{tabular}

\begin{tabular}{|c|c|c|}
\hline $.357 * * *$ & $.174 * *$ & -.377 \\
\hline $.171 * * *$ & .055 & -.155 \\
\hline $.124 * *$ & .096 & -.038 \\
\hline .025 & $.139 * *$ & .200 \\
\hline
\end{tabular}

Table 2

Results moderated regression models

* $\quad$ significant at $\alpha=0.1$

** significant at $\alpha=0.05$

*** significant at $\alpha=0.01$

\subsection{Hypotheses testing}

The table above shows that the effect of the various antecedents to consumer trust in e-retailing are not the same for both country models. However, it can be stated that all processes are used in the course of trust formation. The U.S. models show significant effects for perceived investment 
and control (calculative), similarity (intentionality), reputation, word-of-mouth and information from friends and relatives (transference) in both models. Moreover, variables that are statistically significant only in model 2, thus for buyers without experience, are experience over time (predictive), knowledge on information practices (capability) and familiarity (intentionality). For the Italian sample, a similar picture can be drawn, where perceived investment and control (calculative) and perceived similarity (intentionality) are significant predictors for consumer trust in both models. In addition, non-experienced buyers (model 2) perceive experience over time (prediction), knowledge on security issues (capability) and information from neutral sources (transference) as having a significant impact on their trust formation process.

\section{Hypotheses 1a/1b: Power distance/Uncertainty avoidance moderate calculative process - supported}

When testing both hypotheses regarding the calculative process, the antecedents perceived investment and perceived control are considered. Investment as well as control show to be significant for both countries in both models (table 2). The coefficients of the interaction variable country*investment are $0.614(\mathrm{p}<0.01)$ and $0.466(\mathrm{p}<0.01)$ in models 1 and 2 , respectively, and indicate that there is a significant difference in trust formation between the two countries studied. The interpretation of the interaction variable's coefficient changes slightly compared to the interpretation of the independent variables. The moderated coefficient now represents the unit change in the effect of the moderated variable as the moderator changes. In other words, the coefficient of $0.614(0.466)$ indicates that as the moderator country changes from U.S. students (0) to Italian students (1), there is a significant difference in the effect of the linear variable investment on trust. The positive sign of the coefficients indicates that the relationship is strengthened. The coefficients thus indicate that Italians make more use of the antecedent perceived investment compared to their U.S. counterparts when building trust online. In sum, the empirical evidence supports hypotheses $1 \mathrm{a}$ and $1 \mathrm{~b}$ stating that consumers from high power distance and high uncertainty avoidance countries tend to make more use of the calculative trust formation process compared to their counterparts from low power distance and low uncertainty avoidance cultures. 
Hypothesis 2a/2b: Power distance/Uncertainty avoidance moderate prediction process - not supported

The prediction process in trust formation is described by the determinants experience over time, communication and satisfaction. The variable experience over time is statistically significant in model 2 with $b=0.148(p<0.01)$ for the U.S. and $b=0.169(p<0.05)$ for Italy. Congruent to the evidence found in previous research, neither satisfaction nor any of the communication variables effect consumer trust in e-retailing (Walczuch et al. 2001). Although experience over time influences consumer trust for participants who have never made online purchases, no interaction effects with the moderator country are observable. Therefore, no evidence is found for the propositions that societies with large power distance and a high degree of uncertainty avoidance prefer to use prediction-based antecedents of consumer trust. Thus, Hypotheses $2 \mathrm{a}$ and $2 \mathrm{~b}$ fail to be supported.

\section{Hypotheses 3a/3b: Power distance/Uncertainty avoidance moderate capability process - not supported}

Knowledge on information practices and knowledge on security issues are the two antecedents that fall under the capability process of trust formation. Model 2 for both countries shows a significant effect of the variable knowledge on information practices with $b=0.114$ (US) and $b=0.127$ (ITA) significant at an alpha level of 0.05 . Thus, buyers who have more information on how retailers handle their private information will trust more in an online buying relationship. Furthermore, the variable knowledge on security issues was significant for Italians in model 2. The coefficient of $-0.107 \quad(\mathrm{p}<0.1)$ indicates that the group of consumers including the inexperienced buyers who have acquired knowledge on security issues will trust less. This relationship is contradictory to earlier assumptions. Typically, more knowledge is related to more trust. Nevertheless, no statistically significant effects can be observed for one of the knowledge interaction variables on consumer trust. Thus, the analysis does not show any evidence that one of the observed countries makes more use of this knowledge than the other. Consequently, hypotheses $3 \mathrm{a}$ and $3 \mathrm{~b}$ concerning the relative importance of the capability trust formation process in different power distance/uncertainty avoidance societies cannot be supported. 
Hypotheses 4a/4b: Power distance/Uncertainty avoidance moderate intentionality process - not supported

The intentionality process comprises the determinants information from marketer dominated sources, perceived similarity, perceived normality and perceived familiarity. Neither the variable information from marketer dominated sources nor normality show empirical evidence for influencing the dependent variable trust. Nevertheless, the antecedent perceived similarity shows statistically significant results in both models for both countries (table 2). This indicates that perceived similarity between the buyer and the e-retailer does increase trust. Furthermore, the variable familiarity has a direct effect on trust in model 2 for the Italian sample $(b=0.106$ at $\mathrm{p}<0.05)$. However, no significant interaction effect supporting the hypothesis of increased use of the intentionality trust formation process by low power distance/uncertainty avoidance cultures could be found. Therefore, hypotheses $4 \mathrm{a}$ and $4 \mathrm{~b}$ cannot be supported.

\section{Hypothesis 5a: Power distance moderates transference process: supported}

Reputation of the e-retailer, word-of-mouth, information from friends and relatives and information from neutral sources form the group of transference-based trust antecedents.

In this study, support for the antecedents word-of-mouth (for both countries at $\mathrm{p}<0.01$ in model 1) and perceived reputation (for both countries at $\mathrm{p}<0.01$ in model 1 and for Italy at $\mathrm{p}<0.05$ in model 2 ) is found in both regressions. Thus, second hand information does have some influence on consumer trust in e-retailing. Moreover, the variable word-of-mouth combined with the country moderator also shows significant results in model 1 . The coefficient equals -0.25 (at $p<0.1$ ). The relationship between word-of-mouth and consumer trust is therefore attenuated by the country variable. This indicates that U.S. respondents make significantly more use of this antecedent in their trust creation process compared to Italian participants. These results for the United States, being a low power distance and low uncertainty avoidance country, indicate that hypothesis 5a can be supported.

\section{Hypothesis 5b: Uncertainty avoidance moderates transference process: not supported}

The results of hypothesis $5 \mathrm{a}$ are conflicting with hypothesis $5 \mathrm{~b}$, which proposes that high uncertainty avoidance cultures make relatively more use of the transference process than low uncertainty avoidance cultures. However, no attenuating effect of uncertainty avoidance on transference based consumer trust formation is found. One could suggest that the hypothesized 
relationship of $\mathrm{H} 5 \mathrm{a}$ is stronger than that of $\mathrm{H} 5 \mathrm{~b}$ and that the impact of power distance weighs more on the trust formation process than that of uncertainty avoidance. However, H5b cannot be supported in this research.

\section{Discussion}

This research study confirms the findings of several scholars stating cognitive factors, like reputation, word-of-mouth, information from friends and relatives, perceived similarity and perceived control are the building blocks of institution-based consumer trust for experienced buyers (Jarvenpaa and Tractinsky 1999, Walczuch et al. 2001). For those participants who have never actually bought or intended to buy a product online, knowledge and experience-related antecedents additionally come into play. Antecedents like familiarity (U.S.), experience over time and knowledge on information practices and knowledge on security issues (ITA) increase consumer trust when the experience level in online purchasing is low. Thus, the formation of online trust is a rational process. In addition, this study presents empirical evidence for Doney et al.'s (1998) trust formation model by confirming the use of all five cognitive processes.

The main contribution of this paper is that it advances cross-cultural research finding empirical evidence for the impact of power distance and uncertainty avoidance on the trust formation processes in e-retailing. Significant differences between the two countries, and thus cultures, show.

Consumers from high power distance and high uncertainty avoidance cultures tend to form trust more through a calculative process as compared to their counterparts in low power distance/uncertainty avoidance cultures. As hypothesized, members of a high power distance and high uncertainty avoidance culture like Italy consider opportunistic behavior in their trust formation process. The perceived investment of e-retailers in their online stores is an indicator of the possibilities to act opportunistically.

In contrast, these low power distance and low uncertainty avoidance societies, like the U.S.A, make more use of a transference trust formation process. In the U.S., where the general level of trust is high, the faith in people and institutions is high as well. As a result, a smooth passing on of trust from one person to another through e.g. word-of-mouth, can be found in low power distance and low uncertainty avoidance cultures. 
No cultural differences in the use of prediction, capability and intentionality trust formation processes could be found in this study.

This research has furthermore shown that power distance and uncertainty avoidance have an effect on the overall level of trust. Low power distance and low uncertainty avoidance cultures, as represented by the U.S.A in this research, are generally more trusting in e-retailing as compared to high power distance and high uncertainty avoidance countries, like Italy. This is in line with earlier research by Fukuyama (1995).

\subsection{Practical Implications}

In terms of practical implications of this study, e-retailers should market their products to customers from low power distance and low uncertainty avoidance cultures by enabling and encouraging the passing on of second hand information. Product specific chat rooms, consumer discussion forums and consumer-to-consumer evaluations can be useful tools to achieve this aim. Moreover, simply following sound business practices will foster positive word-of-mouth, which consequently increases trust. On the other hand, online retailers wanting to sell in high power distance and high uncertainty avoidance countries must understand that it will be harder for them to establish trust with their potential customers. To support the calculative trust formation process by e.g. making the store size apparent to the buyer, especially if the e-retailer has a long retailing history and high sales volumes, is one of the techniques that should be applied. For small eretailers this implies that strategic partnerships and buy-outs of competitors will be beneficial for the investment that the buyers perceive and thus their trust that they will devote to large eretailers. In addition, one might speculate that large brick-and-mortar stores will find it easier to establish online trust relationships in high power distance and high uncertainty avoidance countries since their size is already known. The recognition of these cultural priorities is crucial to a successful e-retailing strategy.

\subsection{Limitations and Further Research}

Taking students as target group of this research can be seen as a limitation of this research study. On the one hand, students are a very good target group for a research study in the field of eretailing, since the students participating in this study have free access to the Internet and have the opportunity to use this medium for communication and commercial transactions. Also, students regularly buy products, which are well suited for e-retailing, namely books, CDs and the like. 
Often these products are offered for lower prices online than offline, which forms a strong incentive to engage in e-retailing for this group.

Our analysis shows that the Italian students were less experienced with the Internet than the U.S. students. The question remains whether the later stage of Internet adoption in Italy partially explains the lower level of online consumer trust among our Italians participants and whether this lack of experience influences the set of significant cognitive antecedents of consumer trust in eretailing. Alternatively, could the lower trust level among our Italian students be the reason for the observed lower Internet use?

The two sampled cultures in this research are both individualistic and masculine societies but distinguish themselves on the power distance and uncertainty avoidance dimensions, on which the United States scores low but Italy scores relatively high. These distant positions that the U.S. and Italy take on the distinguishing dimensions results in unambiguous findings when testing hypotheses 1 through 4. However, the results of hypothesis 5, where H5a and H5b portray contradictory positions, are ambiguous. In addition, our study only researched the combined moderating effect of power distance and uncertainty avoidance but does not discern between the separate influences of these two culture dimensions. The findings in this research can thus be interpreted in different ways. In order to test, which hypothesized influence on the transference based trust process holds, it would be interesting to analyze a new sample of two countries that differ only on either the power distance or the uncertainty avoidance dimension. For example, to the existing sample of Italian students, a new set of students from South Africa could be added, as South Africa can be described as an individualistic, masculine, high power distance culture, which, in contrast to Italy, scores low on uncertainty avoidance. Secondly, the effect of Hofstede's (1997) remaining culture dimensions, namely individualism/collectivism and masculinity/femininity, could be tested when extending the trust formation model. Further research pursuing these suggestions will yield more insight into the nature of moderated trust in e-retailing. 


\section{References}

Ba, S. 2001. Establishing Online Trust through a Community Responsibility System. Decision Support Systems. 31 323-336.

Brehm, S. S., S. M. Kassin, S. Fein. 1998. Social Psychology, Houghton Mifflin, Boston, MA.

de Mooij, M. 2001. Convergence and Divergence in Consumer Behaviour. World Advertising Research Center. 30-33.

Deutsch, M. 1958. Trust and Suspicion. Journal of Conflict Resolution. 2 (4) 265-279.

Doney, P. M., J. P. Cannon. 1997. An Examination of the Nature of Trust in Buyer-Seller Relationships. Journal of Marketing. 61 (2) 35-52.

Doney, P. M., J. P. Cannon, M. R. Mullen. 1998. Understanding the Influence of National Culture on the Development of Trust. Academy of Management Review. 23 (3) 601-620.

EconomistIntelligenceUnit. 2002. The Economist Intelligence Unit E-Readiness Rankings. http://www.ebusinessforum.com/index.asp?layout=printer_friendly\&doc_id=5768. Last accessed on: November 21, 2002.

French, T., S. Minocha, A. Smith. 2002. E-Finance Localisation: An Inormal Analysis of Specific E-Culture Attractors in Selected Indian and Taiwanese Sites. http://www.optimumweb.co.uk/iwips/IWIPS2002_efinance.htm. Last accessed on: October 22, 2002.

Friedman, B., P. H. Kahn, D. C. Howe. 2000. Trust Online. Communications of the ACM. 43 (12) 34-40.

Fukuyama, F. 1995. Trust: The Social Virtues and the Creation of Prosperity, The Free Press, New York, NY.

Ganesan, S. 1994. Determinants of Long-Term Orientation in Buyer-Seller Relationships. Journal of Marketing. 58 1-19.

Garbarino, E., M. S. Johnson. 1999. The Different Roles of Satisfaction, Trust, and Commitment in Customer Relationships. Journal of Marketing. 63 70-87.

Gefen, D. 2000. E-Commerce: The Role of Familiarity and Trust. Omega. 28 725-737.

Gefen, D., E. Karahanna, D. Straub. 2003. Trust and TAM in Online Shopping: An Integrated Model. MIS Quarterly. 27 (1) 51-90.

Grant, E. 2002. Study: E-Commerce To Top \$1 Trillion by 2002. http://www.ecommercetimes.com/perl/story/16314.html. Last accessed on: November 11, 2002. 
Heijden, H. v. d., T. Verhagen, M. Creemers. 2000. Predicting Online Purchase Behavior: Replications and Tests of Competing Models. Research Momoranda 16. Free University Amsterdam.

Hofstede, G. 1983. The Cultural Relativity of Organizational Practices and Theories. Journal of International Business Studies. (Fall) 75-89.

----- 1997. Cultures and Organizations: Software of the Mind, McGraw Hill, New York, NY.

Jarvenpaa, S. L., N. Tractinsky. 1999. Consumer Trust in an Internet Store: A Cross-Cultural Validation. Journal of Computer-Mediated Communication. 5 (2)

Jarvenpaa, S. L., N. Tractinsky, M. Vitale. 2000. Consumer Trust in an Internet Store. Information Technology and Management. 1 45-71.

Kale, S. H., R. P. McIntyre. 1991. Distribution Channel Relationships in Diverse Cultures. International Marketing Review. 8 (3) 31-45.

Kang, K.-S., B. Corbitt. 2001. Effectiveness of Graphical Components in Web Site E-Commerce Application - A Cultural Perspective. Electronic Journal on Information Systems in Developing Countries. 7 (2) 1-6.

Karvonen, K., L. Cardholm, S. Karlsson. 2000. Cultures of Trust: A Cross-Cultural Study on the Formation of Trust in an Electronic Environment. Proceedings of the Nordic Workshop on Secure IT Systems. Reykjavik, Iceland.

Kersten, G. E., S. Matwin, S. Noronha, M. A. Kersten. 2000. The Software for Cultures and the Cultures for Software. Proceedings of the European Conference on Information Systems. Vienna, Austria.

Kim, K., B. Prbhakar, B. H. Kim. 2001. Initial Trust as a Determinant of the Adoptinon of Internet Banking. http://mri.inha.ac.kr/article/8-1/banking\%5d.PDF. Last accessed on: November 5, 2002.

Kramer, R. M. 1999. Trust and Distrust in Organizations: Emerging Perspectives, Enduring Questions. Annual Review of Psychology. 50 569-598.

Lynch, P. D., R. J. Kent, S. S. Srinivasan. 2001. The Global Internet Shopper: Evidence from Shopping Tasks in Twelve Countries. Journal of Advertising Research. 4 (2) 15-23.

Mayer, R. C., J. H. Davis. 1995. An Integrative Model of Organizational Trust. Academy of Management Review. 20 (3) 709-734.

McKnight, D. H., V. Choudhury, C. Kacmar. 2002. Developing and Validating Trust Measures for E-Commerce: An Integrative Typology. Information Systems Research. 13 (3) 334359. 
McKnight, D. H., L. L. Cummings, N. L. Chervany. 1998. Initial Trust Formation in New Organizational Relationships. Academy of Management Review. 23 (3) 473-490.

Noeteberg, A., E. Christiaanse, P. Wallage. 1999. The Role of Trust and Assurance Services in Electronic Channels: An Exploratory Study. Proceedings of the International Conference on Information Systems (ICIS). Charlotte, NC.

Nooteboom, B. 2002. Trust, Edward Elgar, Cheltenham, UK.

NUA. 2002. How Many Online?

http://www.nua.com/surveys/index.cgi?f=VS\&art_id=899297592\&rel=true. Last accessed on: November 11, 2002.

Nunally, J. C. 1978. Psychometric Theory, McGraw-Hill Book Company, New York, NY.

Parkhe, A. 1998. Understanding Trust in International Alliances. Journal of World Business. 33 (3) 219-239.

Raven, P., C. P. Fleenor. 2002. Feasibility of Global E-Business Projects. http://www.seattleu.edu/asbe/igbi/publications/Global_EBusiness.pdf. Last accessed on: November 5, 2002.

Rempel, J. K., J. G. Holmes, M. P. Zanna. 1985. Trust in Close Relationships. Journal of Personality and Social Psychology. 49 (1) 95-112.

Sambamurthy, V., S. Jarvenpaa. 2002. JSIS Editorial - Special Issue on "Trust in the Digital Economy". Journal of Strategic Information Systems. 11 (3-4) 183-185.

Singh, T., J. V. Jayashankar, J. Singh. 2001. E-Commerce in the U.S. and Europe - Is Europe Ready to Compete? Business Horizons. 44 (2) 6-16.

Smith, A., T. French, S. Minocha, L. Dunckley. 2002. Culture and Website Usability: Strategies for Internationalisation and Localisation. Proceedings of the HCI Conference. London.

Triandis, H. 1994. Culture and Social Behavior, McGraw-Hill, New York, NY.

Triandis, H., Suh. 2002. Cross-Cultural Psychology. http://www.sinica.ed.tw/ kuoshu/people/triandis/triandis.doc. Last accessed on: November 7, 2002.

Walczuch, R., J. Seelen, H. Lundgren. 2001. Psychological Determinants for Consumer Trust in E-Retailing. Proceedings of the Research Symposium on Emerging Electronic Markets (RSEEM). Maastricht, The Netherlands.

Yamagishi, T., M. Yamagishi. 1994. Trust and Commitment in the United States and Japan. Motivation and Emotion. 23 (2) 109-121. 


\section{Appendix: Constructs measured by the questionnaire}

Unless otherwise indicated, the questions were answered on a 5-point-Likert scale with extremes being strongly agree/strongly disagree.

\begin{tabular}{|c|c|c|}
\hline Construct & Item & Alpha \\
\hline $\begin{array}{l}\text { Trust } \\
\text { (Walczuch et al. 2001) }\end{array}$ & 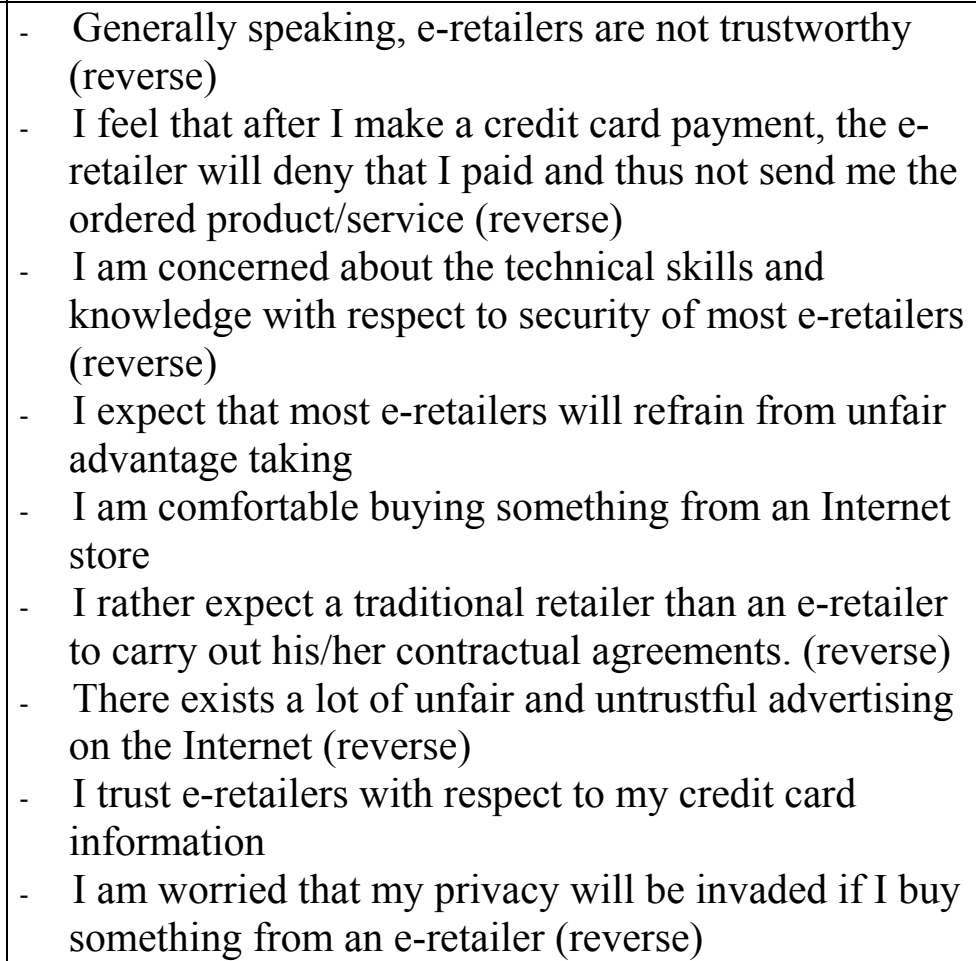 & 0.73 \\
\hline $\begin{array}{l}\text { Reputation } \\
\text { (Ganesan 1994, Walczuch et } \\
\text { al. 2001) }\end{array}$ & 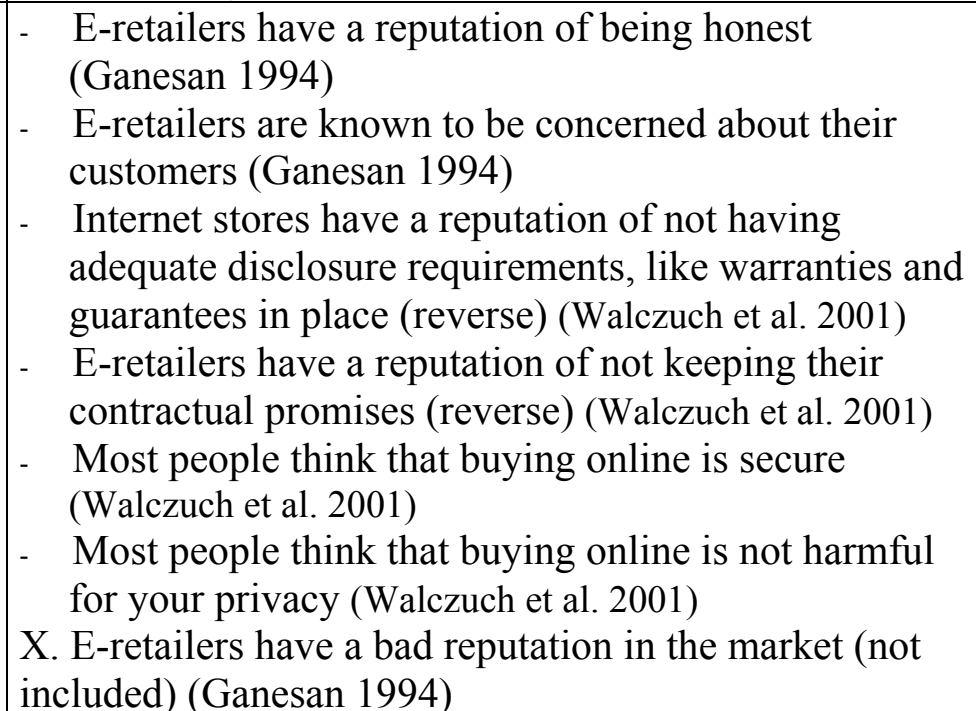 & 0.53 \\
\hline $\begin{array}{l}\text { Information from friends } \\
\text { and relatives } \\
\text { (Walczuch et al. 2001) }\end{array}$ & $\begin{array}{l}\text { Most of my friends and relatives think that e-retailers } \\
\text { are trustworthy }\end{array}$ & $\begin{array}{l}\text { Not } \\
\text { applicable }\end{array}$ \\
\hline
\end{tabular}




\begin{tabular}{|c|c|c|}
\hline $\begin{array}{l}\text { Word-of-mouth } \\
\text { (Walczuch et al. 2001) }\end{array}$ & $\begin{array}{l}\text { I know someone who had bad experiences with } \\
\text { buying online (reverse) }\end{array}$ & $\begin{array}{l}\text { Not } \\
\text { applicable }\end{array}$ \\
\hline $\begin{array}{l}\text { Information from neutral } \\
\text { sources } \\
\text { (Walczuch et al. 2001) }\end{array}$ & $\begin{array}{l}\text { There is a lot of negative information in the media } \\
\text { (TV, radio, newspapers, periodicals, etc. about } \\
\text { buying online (reverse) } \\
\text { - According to consumer reports it is not advisable to } \\
\text { buy from an Internet store (reverse) }\end{array}$ & $\begin{array}{l}\text { Not } \\
\text { applicable }\end{array}$ \\
\hline $\begin{array}{l}\text { Information from marketer } \\
\text { dominated sources } \\
\text { (Walczuch et al. 2001) }\end{array}$ & $\begin{array}{l}\text { E-retailers promote that they are trustworthy } \\
\text { I know advertisements of e-retailers that argue that it } \\
\text { is secure to buy from an Internet store } \\
\text { - I know of e-retailer advertisements that say privacy } \\
\text { will not be invaded when something is bought online }\end{array}$ & $\begin{array}{l}\text { Not } \\
\text { applicable }\end{array}$ \\
\hline $\begin{array}{l}\text { Perceived investment } \\
\text { (Jarvenpaa \& Tractinsky, } \\
\text { 1999) }\end{array}$ & $\begin{array}{l}\text { E-retailers are mostly small players in the market } \\
\text { (reverse) }\end{array}$ & $\begin{array}{l}\text { Not } \\
\text { applicable }\end{array}$ \\
\hline $\begin{array}{l}\text { Perceived similarity } \\
\text { (Doney and Cannon 1997) }\end{array}$ & $\begin{array}{l}\text { I perceive the interests of traditional retailers to be } \\
\text { more similar to mine than the interests of e-retailers } \\
\text { (reverse) } \\
\text { - I perceive the values of e-retailers to be more similar } \\
\text { to mine than the values of traditional retailers } \\
\text { - I perceive e-retailers as being more similar to me } \\
\text { than traditional e-retailer } \\
\text { X. I would rather trust an e-retailer from my own } \\
\text { country than an e-retailer from another country }\end{array}$ & 0.57 \\
\hline $\begin{array}{l}\text { Perceived normality } \\
\text { (Walczuch et al. 2001) }\end{array}$ & $\begin{array}{l}\text { To buy something from an Internet store is not a } \\
\text { common thing to do (reverse) } \\
\text { - Most people do not think that it is normal to buy } \\
\text { products from an e-retailer (reverse) } \\
\text { It is not commonly accepted to buy something from } \\
\text { an e-retailer (reverse) }\end{array}$ & 0.57 \\
\hline $\begin{array}{l}\text { Perceived control } \\
\text { (Walczuch et al. 2001) }\end{array}$ & $\begin{array}{l}\text { There exist adequate laws that will protect me when I } \\
\text { make online purchases } \\
\text { - Many e-retailers make use of seals of approval like } \\
\text { Visa, Etrust and SET which will protect me when I } \\
\text { make online purchases } \\
\text { - Many e-retailers do not have adequate labeling and } \\
\text { disclosure requirement like warrantees, guarantees, } \\
\text { product standards and specifications in place } \\
\text { (reverse) } \\
\text { In my opinion, e-retailers have adequate mechanisms } \\
\text { in place that will safeguard me from defective } \\
\text { products } \\
\text { Most e-retailers do not have conditions of } \\
\text { cancellation in place (reverse) }\end{array}$ & 0.66 \\
\hline
\end{tabular}




\begin{tabular}{|c|c|c|}
\hline & $\begin{array}{l}\text { If an e-retailer posts a privacy policy on his/her } \\
\text { Website I would trust that e-retailer to follow the } \\
\text { policy } \\
\text { - Most e-retailers have an appropriate refund } \\
\text { mechanism in place }\end{array}$ & \\
\hline $\begin{array}{l}\text { Perceived familiarity } \\
\text { Adapted from (Garbarino } \\
\text { and Johnson 1999, Walczuch } \\
\text { et al. 2001) }\end{array}$ & 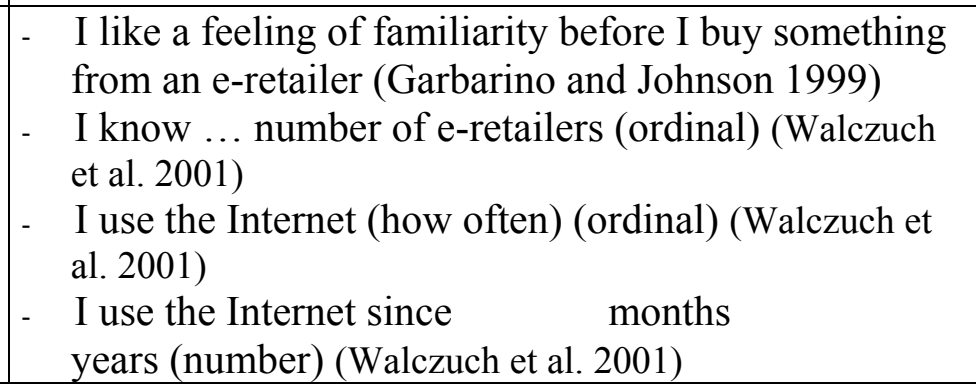 & $\begin{array}{l}\text { Not } \\
\text { applicable }\end{array}$ \\
\hline $\begin{array}{l}\text { Experience over time } \\
\text { (Walczuch et al. 2001) }\end{array}$ & $\begin{array}{l}\text { Have you made purchases from e-retailers in the } \\
\text { past? (nominal) } \\
\text { - How many times did you buy something from an e- } \\
\text { retailer? (ordinal) } \\
\text { - I buy things from the Internet since } \\
\text { years (number) }\end{array}$ & $\begin{array}{l}\text { Not } \\
\text { applicable }\end{array}$ \\
\hline $\begin{array}{l}\text { Satisfaction } \\
\text { (Walczuch et al. 2001) }\end{array}$ & $\begin{array}{l}\text { - My experiences with e-retailers were always positive } \\
\text { My experiences with e-retailers were as satisfactory } \\
\text { as my experiences with traditional retailers } \\
\text { - I felt pleased with respect to the outcomes of the last } \\
\text { five times I bought something online }\end{array}$ & 0.85 \\
\hline $\begin{array}{l}\text { Communication } \\
\text { independent of buying } \\
\text { process } \\
\text { (Walczuch et al. 2001) }\end{array}$ & $\begin{array}{l}\text { The e-retailers I have experience with have problems } \\
\text { answering my questions (reverse) } \\
\text { - The e-retailers I have experience with are responsive } \\
\text { to my needs of information } \\
\text { - I always knew what the privacy policy of the e- } \\
\text { retailers I have experience with was } \\
\text { - I always knew what the security policy of the e- } \\
\text { retailers I have experience with was }\end{array}$ & 0.72 \\
\hline $\begin{array}{l}\text { Communication of } \\
\text { expectations } \\
\text { (Walczuch et al. 2001) }\end{array}$ & $\begin{array}{l}\text { When I ordered a product from an e-retailer I always } \\
\text { knew when I could expect the product to be delivered } \\
\text { It was always clear to me what I had to pay for the } \\
\text { ordered products or services }\end{array}$ & 0.43 \\
\hline $\begin{array}{l}\text { Communication } \\
\text { intentions } \\
\text { (Walczuch et al. 2001) }\end{array}$ & $\begin{array}{l}\text { - If something was not in stock it was clear to me } \\
\text { when it would be replenished } \\
\text { - It was always clear to me that the seller had really } \\
\text { received my order and thus that he would deliver the } \\
\text { ordered product } \\
\text { - It was clear to me when the e-retailer would ship the } \\
\text { ordered product }\end{array}$ & \begin{tabular}{|l|}
0.70 \\
\end{tabular} \\
\hline Communication & $\begin{array}{l}\text { The e-retailers I have experience with provided me } \\
\text { with information about the applicable law system to }\end{array}$ & 0.79 \\
\hline
\end{tabular}




\begin{tabular}{|c|c|c|}
\hline $\begin{array}{l}\text { retaliation } \\
\text { (Walczuch et al. 2001) }\end{array}$ & $\begin{array}{l}\text { this particular contract } \\
\text { It was always clear to me if I had the possibility to } \\
\text { return the ordered products } \\
\text { - It was always clear to what I had to do if something } \\
\text { was not as expected } \\
\text { If problems such as shipment delays arise, the e- } \\
\text { retailers I have experience with are honest about the } \\
\text { problems } \\
\text { The e-retailers I have experience with provided me } \\
\text { with information about the conditions with respect to } \\
\text { for example cancellation, payback mechanisms and } \\
\text { conflict resolution }\end{array}$ & \\
\hline $\begin{array}{l}\text { Communication } \\
\text { absolution } \\
\text { (Walczuch et al. 2001) }\end{array}$ & $\begin{array}{l}\text { If something would not go as expected, the e-retailer } \\
\text { will give me the idea this would not happen the next } \\
\text { time } \\
\text { The e-retailer offered me something extra, like for } \\
\text { example a discount, if something would go wrong } \\
\text { with the delivery }\end{array}$ & 0.70 \\
\hline $\begin{array}{l}\text { Knowledge of information } \\
\text { practices } \\
\text { (Walczuch et al. 2001) }\end{array}$ & $\begin{array}{l}\text { I believe that e-retailers can without my knowledge } \\
\text { obtain my name and address from Internet usage } \\
\text { (reverse) } \\
\text { Third parties can without my knowledge obtain the } \\
\text { information that I have given to an e-retailer } \\
\text { I believe that e-retailers can without my knowledge } \\
\text { obtain my name and address from buying on the } \\
\text { Internet (reverse) } \\
\text { I believe that e-retailers can without my knowledge } \\
\text { obtain my e-mail address from Internet usage } \\
\text { (reverse) } \\
\text { I believe that e-retailers can without my knowledge } \\
\text { obtain information about my surfing behavior }\end{array}$ & $\begin{array}{l}\text { Not } \\
\text { applicable }\end{array}$ \\
\hline $\begin{array}{l}\text { Knowledge about security } \\
\text { technology } \\
\text { (Walczuch et al. 2001) }\end{array}$ & $\begin{array}{l}\text { I know what SET is } \\
\text { A message locked with a certain public key can only } \\
\text { be opened with the corresponding public key } \\
\text { (reverse) } \\
\text { - My browser indicates when I enter a secure area } \\
\text { - All secure servers are technically the same and are } \\
\text { equally secure (reverse) }\end{array}$ & $\begin{array}{l}\text { Not } \\
\text { applicable }\end{array}$ \\
\hline
\end{tabular}

